D Alontana vauy Statutes etc.

State foust wand facus,

$$
1909+1911
$$




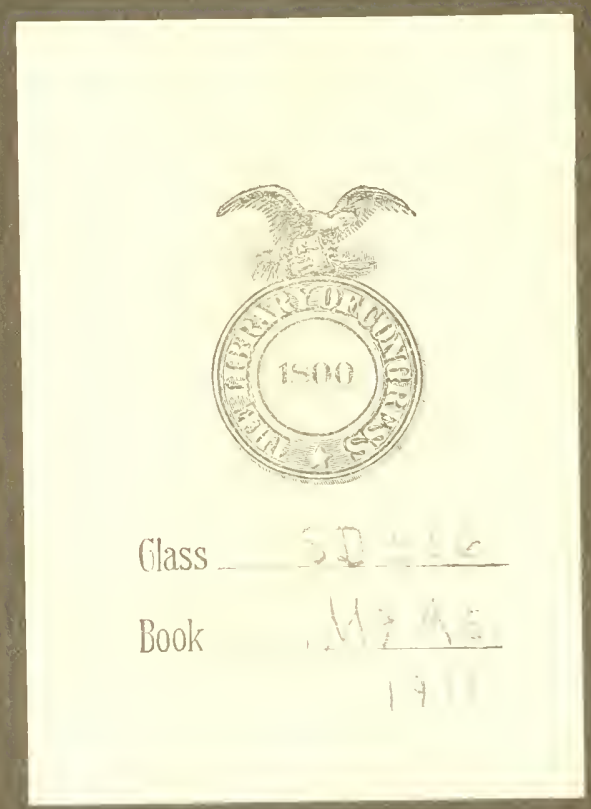

Class

Book

$$
1+11
$$




\section{STATE FOREST}

\section{LAND LAWS}

ENACTED

Sessions 1909 and 1911

CHAPTER 147-1909

CHAPTER 119-1911

Published by

Montana State Forestry Board 
D. of D.

APR $6 \quad 1916$

$\therefore \vdots$ 


\section{CHAPTERS 147 and 119}

\section{Montana Session Laws 1909 and Amend-}

ments by Legislative Assembly of the State of Montana, 1911

An Act providing for the Management and Control of the Forest Lands now owned by or hereafter to be acquired by the State of Montana, including the Sale thereof, and the Management, Protection, and Disposition of the Timber Growing thereon; Naming and Providing for Certain Offcers subordinate to the State Board of Land Commissioners and prescribing their Duties and Compensation; and Defining and Providing for the punishment of Certain Offenses for Violating the Provisions of this Act. 


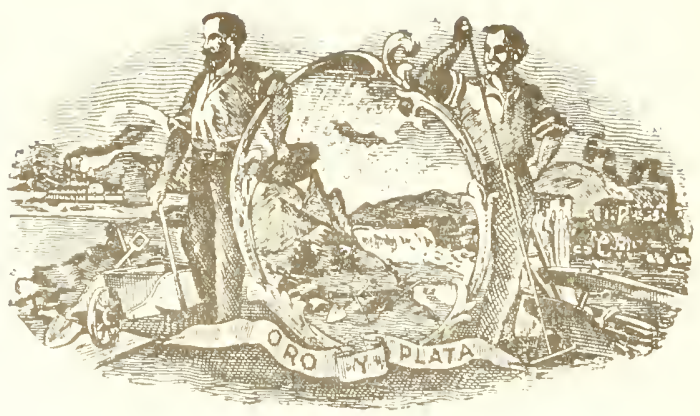




\section{State Forestry.}

Section IX. The Governor, by and with the advice and consent of the Senate, shall appoint a state forester. who shall be skilled in the science of forestry, whose salary shall be twentyfive hundred (2500) dollars per annum, and actual necessary expense while engaged in outside work, comnected with his office, and whose term of office shall be four years, or until his successor shall be appointed and qualified, and he shall give a bond to the state in the smm of ten thousand $(10,000)$ dollars, to be approved by the board and filed with the Secretary of State; and he shall be a civil executive officer.

\section{Duties of State Forester.}

Section $X$. The state Forester shall, under the direction and control of the State Boarl of Land Commisuinners, do all the field work in the selection. location, eximination, appraisement. and re-appraisement of state timber lands. whether now belonging to the state or hereafter granted to the state: he shall do all acts resulired of him to be performed by the said board, and under the directron of said buard shall have general charge of the timber lands of the state. He shall act as secretary of the Forestry Boarl. Le shall, under the smpervision of the State Board of Land Commissioners. execute all matters pertaining to forestry within the jurisdietion of the state; have charge of all tire warlens of the state, and direct and ait them in their duties; direct the protection and improvement of state parks and forests: take such action as is authorized by law to prevent and extenguish forest, brush. and grass fires: enforce the laws pertaining to forest and brushcovered lands, and prosectute for any violation of such laws. He shall deliver a course of at least six lectures on practical forestry to the students attending the State University, the State Agricultural College, and the State Normal Schoul, during each school year. He shall prepare annually a report to the Gorernor on the progress and condition of the state forest work, and recommend therein plans for improving the state system of forest protection, management and replacement. He shall furnish intices, printed in large letters on cloth, calling 
attention to the danger from forest fires, and to the forest fire and trespass laws and their penalties. Sucl notices shall be posterl by the fire warden in conspicuous places in the several comnties of the state, and particularly in brush and forest covered conntry, at frequent intervals along streams and lakes frequented by tourists, hunters, and fishermen, at established camping sites, and in every postoffice in the forested region.

\section{Fire Wardens.}

Section XI. The state forester shall apjwint in such number and localities as he leems wise, public spirited itizens to act as volunteer fire wardens. Every sheriff, mnder sheriff, deputy sheriff, game warden and leputy game warden, shail be ex-officio a fire warlen, but shall not receive any additicnal compensation by reason of the duties hereby imposed, and they shall be deemed paid fire wardens moler the terms of this act. The supervisors and rangers of the federal forest reserves within this state, whenever they formaliy accept the duties and responsibilties of fire warlens, may be appointed volunteer fire wardens, and shall have all the powers given to fire wardens by this act. The fire warlens shall promptly report all fires to the state board of forestry, take immediate and active steps to-ward their extinguishment; report any rolation of forest laws; and assist in apprehending and conricting the offenders.

\section{Powers of Fire Wardens.}

Section XII. The state frrester, and all fire wardens, shall have the power of peace officers to make arrests without warrants for vinlations, in their presence, of any state or federal forest laws, and 110 fire warden shall he liable for civil action for trespass committed in the dicharge of their duties. Any fire warden who has information which shows, with reasonable certainty. that any person has violated any provision of such forest laws shall inmediately take action against the offender by making complaint lefore the proper magistrate. or by information to the proper comty attorney, and shall obtain all possible evillence pertaining theretr. Failure on the part of any paid fire wardon to comply with the duties prescribed in this act, shall he a mislemeanor, and punishable by a fine of not less than twenty dollars, nur more than one thousand dollars, or imprisonment in the comnty jail for not less than ten days nor more 
than twelve months, or by buth such fine and imprisonment; and upon his conviction the district court wherein he is convicted shall forthwith declare lis office racant, and notify the proper appointing power thereof.

\section{Additional Powers of Fire Wardens.}

Section NIII. All fire wardens shall have anthority to call upon any able bodied citizen hetween the ages of eighteen and fifty years, resident in the ricinity, for assitance in putting out fires; and any such person who refuse to obey such summons, except for good and sufficient reason, is guilty of a

- misdemeanor, and upon conviction, shall he fined $i_{11}$ the sum of not less than fifteen nor more than fifty dollars, or imprisonment in the county jai! not less than one nor more than thirty days, or hoth. such fine and imprisonment; provided, that no citizen shall be called upon to fight fire a total of more than fire days in one vear.

\section{Duties of Fire Wardens.}

Section XIV. The state forester, assistant forester, and all fire wardens (except volunteer wardens), mnder such rules and regulations as the state board of land commissioners may provide, shall protect the timber of the state, and especially the timber owned by the state, from destruction by fire, and for such purpose, in emergencies, may employ men and incur other expenses, when necessary: provided, that no fire warden shall incur any expense in excess of fifty dollars. Without express authority of the state board of land c:mmissioners.

\section{Expenses of State Forester.}

Section XV. That the actual expenses and expenditures of the state forester, asistant forester and fire wardens necessarily incurred under this act, shall be paid in the same manner as are other expenses incurred in managing the state lands.

\section{Penalty for destroying Notices.}

Section XVI. Iny person who shall destroy, delace, remove or disfigure any sign, post or warning notice posted nnder the provisions of this act shall be suilty of a misclemeanor, and punishable upon conviction, by a fine of not less than fifteen dollars and not more than irro hundred and fifty dollars, or imprisomment in the comnty jail for a period of not less than ten 
days nor more than three months, or ly beth such fine and injprisonment.

\section{Prosecutions.}

Section XYll. Mhenever an arrest shall be marle for an! violation of the prorisions of this act, or whenever any information of such riolations shall he lodged with lim, the county attorney of the county in which this act was committed must prosecute the offender w offenders if in his juclgment the facis warrant the same. If any county attorney shall fail to comply with the porisions of this section he shall be guilty of a misdemeanor, and upon consiction, shall he fined not less than one humbled dollars nor more than one thousand dollars: and, upu.n his conviction. the district conrt wherein he is convicted shall forthwith declare his office vacint, amb notify the proper appeinting power thereof. Actirns asainst the comty attorney shall he broweht ly the attorney eneral in the nane of the state. The penalties of this section shall also apply to any masistrate, with proser athority who refuses or neglects to cause the arrest and prosecution of any person or persons. when a complaint moler wath of a riolation of any of the provisions of this act has hesem lociener with him.

\section{Forestry Board.}

Sectim XX. The renister of state lands, together with the state land arent and the state furcster. shall comstitute a for-

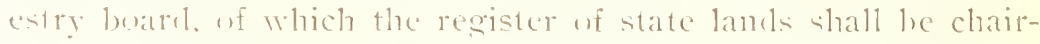
man. I majurity of satid lwarl shall comstitute al yumun for the transatetion of husiness.

\section{Duties of Forestry Board.}

Sextion XYl. It shall be the luty of the Forestry Poard to acertain the methuds of reforestine the denurled forest lands wi the state fo prevent furstry waste. and the destruction of forests ly fire. to manage the forests of the state on forestry

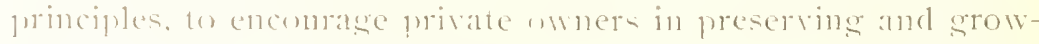
ins timlne and to conserve forest trates around the head waters amb an the water shets of the water comses of the state; it thall make rejurts w its drings and recommendations

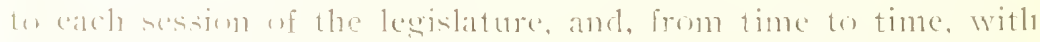

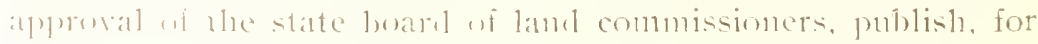
popmlat distributim, such of its enclusions and recommen- 
dations as may be of public interest and concern.

The state board wi forestry may re-forest the water sheds of the state and expend such sums of money therefor as may be appropriated for that purpose by the lesislative assembly.

\section{Assistant Forester.}

Section XXV. The state buard of land commissioners is hereby authorized to appoint one assitant forester, with like qualification as the state forester. at such time or times as may be deened necessary, to assist the state forester in any of the duties of his office; and he shail draw pay only when actually engaged in the performance of such work, and shall hold office at the pleasure of the board, and his pay shall be not to exceed one hundred and fifty (i5o) dollars per nonth, together with actual necessary expenses while engaged in outside work connected with the office. He shill give such bond for the faithful performance of his duties as the state brard of land commissioners may require.

\section{Records of Timber.}

section XXVII. The state board of land commissioners shall cause to be kept accurate records showing the location, extent and character of all forest lanks, and the kind and character of timber growing therom and also an account of all timber sold, the person or persons wo whom suld, the anoment of numey received therefor, and the disposition of the moneys so receiver.

\section{Confirmation of Sales.}

Section XI. All sales of state lands and all sales of timber on state lankls, shall be subject to the approval and cunfirmation by the state board of land commissinners, and no sale shall be deemed completed until after such approval and confirmation.

rection LlII. The state lioard of Land Commisioners shall have power to sell timber on state lands alt such price per thousand feet as in its juclsment shall he for the best interest of the state, but not otherwise; but no such sale of live timber shall be marle at a less price than three dollars per thonsand feet. But no live timber less than eight inches in diameter, twenty feet from the ground, shall be sold or permitted to be cut from state lands. All timber sold or cut from state lands shall be cul and remored muler such rules and res- 
ulations for the preservation of standing timber, and the prevention of fires, as the Sitate lioard of Land Commissioners shall prescribe; in all cases the board must require the person cutting the timber to pile the brush and slashings and dispose of the same in such manner an to prevent forest ires. Before any permit siall be granted, the timber shall be estimated and appraised nuder the direction of the state forester, mpon the request, and subject to the appromal of the State Board of Land (inmulsimers, which estimates and appraisal shall show as nearly as may be the amount and value per thousand feet of all timber measuring not less than eight inches in diameter, wwenty feet from the sround, and also all other timber nuasuring beluw this standard on each tract or lot, together with a statement of the situation of the timber reiative to risk from fires or danage of any kind, its distance from the nearest lake, streanu, (15 railroan, and its value and position as a protection to a water sherl."

section LIV. Nu permit for cutting live timber shall be granted exeent to the highest bideler at a public sale held at the State Cafpitol, notice of which sale shall be published as provider b! law, for the sule of state linds, but no sale shall be made at at less price than the appraised ralue of the tmmen as fixel lyy the State buard ui Land Cimmissioners; and no timber shall be solil after the pasage of this atet wntil the same has heen re-appratiod and estimated since Narch 19, Iyog. Every person purchasing timber at such sale, before the execution of the permit to cut the sime, shall cxecute a bund to the State of Montant, in dumble the amonnt of the estimated value of the timber permitted to be cul, with suficient sureties, to be approved ly the board, comlitioned up,is the pa! ment to the state freasurer of the amonnt that mat be found due under the terms of such permit, and accorling to the provisions of law, and further conditinerl npon the witing of such timber in compliance with such rules and regulations as may be prestibed be the state lonad of lamel Commissioners

Section I. T . VIl promits to cut live timber muder the provisions of this led, hall he made according to a form prescribed by the Ittniney General, and shall he signed by the party applynig for tle same and by the president and secrelary of the State linard of land Commissioners.

Said pernits shall contain a description of the land to be 
cut upon, the estimated amount of timber upon the same, the amount of large timber, required to be left standing, the time within which said timber shall be removed, the price per thousand feet, or the entire value of the timber, if the right to clear the land llas been sold, for which the same was bid in, the stipulated log mark, and such other terms and conditions as may be necessary to make all logs cut under its provisions the absolute property of the state, until the same are pail for. Such permits, when properly executed, shall be recorded in the office of the register of the State Board of Land Connmissioners, and the log mark described therein shall vest the ownership of all logs bearing the same in the State. Provided, Fowever, that the State Board of land Commissioners may authorize the State Forester to issue permits without notice to citizens of Montana to cut and take away dead standing timber under such rules and regulations as to price and guality as may be prescribed by the board, and provided further that. the State forester shall issue permits without notice to cirizens of Montana to cut and take away down timber, witlout price, under such rules and regulations sa may be prescribed by the board.

Section LVI. The State Forester shall select and desirnate a $\log$ mark for each person granted a permit to cut logs upon state lands, which $\log$ mark, when so selected and lesignateri, shall be filed in the office of the register of state lands, and shall be distinctly different from any other log mark selected and designated by him. The State Forester sluall cance all logs so cut to be scaled, and make a detailed report of tine same, to the State Board of Land Commissioners on or before the first day of every nonth. showing the name of the party cutting, the description of the land cut upon, the number we logs cut and marked, the mark placed therenn, the total number of feet, and the value thereof per thomeand, as shown hy the records of this office, stating whether such cutting has been according to the terms of the permit. and. if not properly cut, the consequent damage to the state; and such timber, or logs, shall not be sold, transfored or mannfactured into lumber until the amonut die the state. according to the report of said forester, shall have been paicl in fill: and it shall be the duty of the state forester to report to the State Roari of Land Commissioners all trespass whicl has been, or which 
hereafter be made upon the state timber lands, and all logs cut hy trespassers shall be disposed of as hereinafter provided. siection LVIL. Upon receipt of such report from the State Forester, the Register of State Lands shall draw a draft for the annount upon the party from whom the stumpage is due. If said party slatl immediately make payment of the required anumint, the Register shall execute a release of the logs, and trannfer of the mark thereon; but in no case shall such release (r) transles be made nutil the lien of the state has been fully satisfied. If such purchaser shall not pay the amount of such dralt within ten days after receipt of same, it shall be the duty of the State lioard of Land Commissioners to take possessinn of the lugs in question, and sell the same at public anction (1) satisfy the clam of the state, paying the overplus, if any, after defrayng the cost and expenses of such sale to the party entitled thereto, previded, that if the proceeds of such sale are innufficient to paty the anonnt due upon the purchase price. tenecther with the coste and expenses of the sale the amount of anch deficioncy shall he certified to the Attorney General by the State Loard of Land Commissioners and he shall immedintely proced to collect such deficiency from the purchaser or

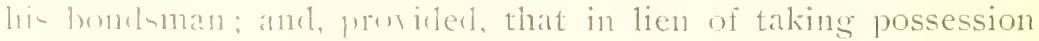
w the logs 11 mon which strunpage is due, the State Board of lamel Comminsoners may turn the acconnt orer to the Atturney (iencral, whe shall immediately proceed to collect the winke upun the lund hereintefore provided for: but in no case shall the logs be released untif the account is paid. The proreding upw the bond shall not prevent the Sitate Poard of

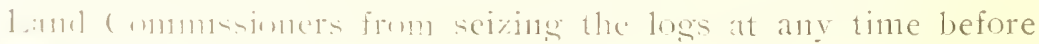
the ditim! of the State is satisfieri.

\section{Penalty for false marks on Timber.}

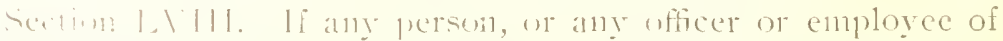
a rorpurallim, hat ing a contract to cut timber under the proinkun of thin act, with intent to defratur the state. place any

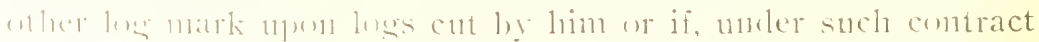

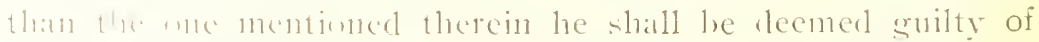

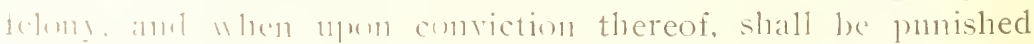
I.) a time of mot less than live flundred Lollars nor more than line Thonsand l)ollarts on ly imprisonment in the State

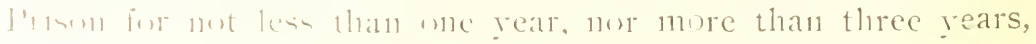


or both: and all logs npon which such false mark has been placed shall be forfeited to the state.

\section{Additional Penalty.}

Section LIX. That in addition to the penalties provided for in this title aganst those committing trespass upon any of the lands owned or lield in trust or otherwise by the State, the State Board of Land Commissioners is hereby anthorized and empowered. withont legal proccss, to seize and take, or cause to be seized and taken, any and all lumber, worl, grass or other property. unlawfully severed from the said lands, whether the same las been removed from said lands or not. and may dispose of the same at either public or private sale, in such manner as will be most conductive to the interests of the State, and all moneys arising therefrom, after deducting the reasonable and necessary expenses of sucli seiznte and sale, shall be a part of the permanent fund to which such lands may belong.

\section{Board Defend Suits.}

Section LX. That fur the pr1rjuse of determining the title to any property seizerl and taken under the prorisions of this Act, the State Boarl of I and Commissioners is herely anthorized and empowered to lefend, in the name of the State, any and all actions that mar be brouglit for that purpose, and to do and perform all thinss necessary to protect the interests of the State.

Section LXT. The State Forester. muder the dircetion of the State Board of Land Commissioners, shall select and designate a brand. which sluall place. or canse to be placerl, upon all timber logs, boards or planks, that may be seized, as provided for in this Act. Iny person. or persons, or any ufficer or employee of any company, association, or corporation, who shall remore. sell or clispose of any property mentioned in this act, after the same has been seized or marked with the state brand. or who sluall erase, deface, cut. or destroy any mark upon any such property, shall. 11pon conviction, be imprisoned in the state prison for a term of not less than one rear, nor more than three years, and be subject to a fine of not less than Five Hundred (\$500.00) Mollars nor more than Five Thousand (\$5.000.00) Dollars. 


\section{Penalty for False Appraisements.}

section XCll. Every person appointed or selected to appratise any of the state Laturls, of the timber thereon who will fully and knowingly makes a fitlse return of any survey ur any classification or appraisal of the value of the land, or of the timber thereon, at variance frum the true classification or value thereof, or without having persunally examined and surveyed the sanle, is punishable as provided in Section \$23t (240) of the Fenal Code.

Timber not to be Cut.

Section XCT. If any pmrchaser uf sitate Land, hefore receiving his title therefor, cuts or destroys any timber on said lanu, more than shall be necessiry in the building and repairing of fences and honse and other necessary buildings thereon, and for fucl for the family of the occmpant, he shall be liable in damages for all such excess, the amount of such damage to be recovered in an action in the nance of the State, to he instituted by the Attorney General, in the comby in which the land is sitwated.

\section{County Commissioners may Protect Forests.}

Section CV. The lioard uf Connty Cummissioners of any connty may provile money for the purposes of forest protection, improvement and management.

\section{Penalty.}

Section ClT. Iny officer or entplusec of the State of Montana suilty of a volation of anv uf the provisions of this Act and wot herein otherwise provilex for in hereby declared suilty of a felony. and shall be punisher by imprisonment in the State Frism for a term not exceding ten years, or by a fune not excecting Five Thousand Dollars, or hy both fune and imprisonment.

\section{Repealing.}

Section CVII. 111 . Lets and parts of Acts in conflict with the provisions of this. Ict are hereby repealed.

\section{When in Force.}

Section ('THI. This let slall be in full force and effect from and after its passace and approval.

ipprover March ith, igr. 
CHAPTER NO. II9.

House Bill No. 409.

"An Act authorizing the issuance of permits to cut and take away timber for domestic purposes from State timber lands." BE IT ENACTED BY THE LEGISLATIVE ASSEMBLI OF THE STATE UF MONTANA:

Section I. The State Board of Land Commissioners are hereby empowered to authorize the State Land Agent or the State Forester to issue permits without notice to bona fide citizens of the State of Montana authorizing such citizens to cut and take away from the timber lands of the State, timber in small quantities to be used by such citizens for domestic building and fuel purposes only, under such rules and regulations as to price and quantity as may be prescribed by the said Board.

Section II. All Acts and parts of Acts in conflict herewith are hereby repealed.

Section III. This Act shall be in full force and effect from and after its passage and approval.

Approved March 7. IOII. 







\section{Gaylord Bros.}

Makets

Sy racuse, N. I
PAT. JAN. 21, 1908 
LIBRARY OF CONGRESS

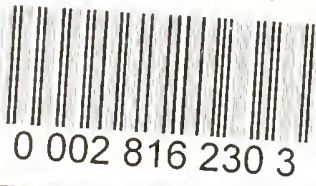

